\title{
LA COERCIÓN ESTATAL DEL ART. 155 CE EN LA ESTRUCTURA DEL ESTADO AUTONÓMICO
}

\author{
LEONARDO ÁLVAREZ ÁLVAREZ \\ Profesor Titular $(A)$ de Derecho Constitucional \\ Universidad de Oviedo ${ }^{1}$
}

SUMARIO

I. Introducción. Coerción estatal en el principio autonómico vs. coerción federal. II. El art. 155 CE como plasmación del principio de lealtad al Estado autonómico. III. La función del art. $155 \mathrm{CE}$ en la estructura del principio autonómico. Coerción estatal y jurisdicción constitucional. IV. La función sustitutiva y el procedimiento de la coerción estatal. V. Conclusiones

\section{INTRODUCCIÓN. COERCIÓN ESTATAL EN EL PRINCIPIO AUTONÓMICO VS. COERCIÓN FEDERAL}

Los desafíos a los que se ha enfrentado en los últimos años el principio de unidad del Estado proclamado en el art. 2 CE de 1978 ha suscitado en el debate político y en el académico la posibilidad de recurrir por primera vez a la aplicación del mecanismo previsto en el art. 155 CE. En la citada disposición se determina que: «si una Comunidad Autónoma no cumpliere las obligaciones que la Constitución u otras leyes le impongan, o actuare de forma que atente gravemente al interés general de España, el Gobierno, previo requerimiento al Presidente de la Comunidad Autónoma y, en el caso de no ser atendido, con la aprobación por mayoría absoluta del Senado, podrá adoptar las medidas necesarias para obligar a aquélla al cumplimiento forzoso de dichas obligaciones o para la protección del mencionado interés general».

Con el art. 155 CE, el constituyente de 1978 pretendió incorporar al principio autonómico una categoría de larga tradición en el funcionamiento de sistema

1 Quiero agradecer a mis compañeros del Área de Derecho Constitucional de la Universidad de Oviedo el debate académico y las observaciones formuladas a este trabajo. 
descentralizado alemán²: la coerción estatal; una facultad reconocida a diferentes órganos del Estado central destinada a asegurar, a través de diferentes medidas, el cumplimiento de las obligaciones impuestas por la Constitución y las leyes al resto de los miembros del sistema descentralizado ${ }^{3}$. La coerción federal ${ }^{4}$, prevista en el art. 37 de la Ley Fundamental de Bonn de 1949, en el que se ha inspirado expresamente el constituyente español, dispone que: «En el caso de que un Estado federado no cumpla con las obligaciones que le impone la Constitución y otras leyes federales, el Gobierno, con el consentimiento del Consejo Federal, podrá adoptar las medidas necesarias para conminar al Estado federado, a través de la coerción federal, al cumplimiento de sus obligaciones» ${ }^{5}$.

El sentido de una facultad de coerción estatal incorporada al art. $155 \mathrm{CE}$ ha recibido hasta el momento escasa atención por parte de la literatura. Los estudios existentes han acabado por asumir, a grandes rasgos, el contenido y la función de la coerción federal para interpretar el supuesto de hecho y las relativamente indefinidas consecuencias jurídicas previstas en el art. 155 CE. Sin embargo, el recurso metodológico al derecho comparado en este caso no arroja resultados concluyentes. No solo porque dicha categoría ha sido objeto de un intenso debate académico en los sucesivos periodos constitucionales, de la que no cabe inferir resultados unívocos ${ }^{6}$. Sobre todo porque el principio autonómico asume unos presu-

2 Véase un resumen de los debates parlamentarios, J. GARcía TORres, «El artículo 155 de la Constitución Española y el principio constitucional de autonomía» en VVAA (edit.), Organización territorial del Estado. Comunidades Autónomas (vol. II), IEF, Madrid, 1984, p. 1202.

3 Véase originariamente el art. XXXI del Acta Final de Viena de 1820. Véase al respecto E.-R. HUBER, «Bundesexekution und Bundesintervention. Ein Beitrag zur Frage des Verfassungsschutzes un deutschen Bund», Archiv des öffentlichen Rechts, n. ${ }^{\circ} 1,1953$, pp. 1 y 2.

4 Heredera de la Reichs / Bundesexekution de la confederación. Por influjo de estos precedentes, parte de la literatura española ha denominado al art. $155 \mathrm{CE}$ como una facultad de ejecución estatal. Véase E. AlberTí Rovira, «La resolución de conflictos entre el Estado y las Comunidades Autónomas» en E. Aja y otros, Sistema jurídico de las Comunidades Autónomas, Tecnos, Madrid, 1985, p. 471. Otros autores han optado por el término coerción o «coacción estatal», a similitud de la categoría de la Bundeszwang empleada para definir en la Ley Fundamental de Bonn, el mecanismo previsto en el art. 37, al que se ha remitido el constituyente de 1978. Véase al respecto, E. Virgala Foruria, «La coacción estatal del artículo 155 de la Constitución», Revista Española de Derecho Constitucional, n. ${ }^{\circ} 73,2005$. Puede verse también, en lo que se refiere a su presencia de otros sistemas, el trabajo de G. Gómez Orfanel, «La coerción federal en el derecho comparado», Cuadernos de Derecho Público, 25, 2005.

5 En lo que se refiere a los precedentes de esta categoría, véase el art. 19 de la Constitución del Reich alemán de 1871: «En el caso de que alguno de los miembros del Bund no cumpla con las obligaciones impuestas por la Constitución, éstas pueden ser exigidas a través de la ejecución. Ésta es decidida por el Bundesrath y ejecutada por el Kaiser». Por su parte, el art. 48,1 de la Constitución de Weimar de 1919 determinaba: «cuando un Land no cumpla con las obligaciones impuestas por la Constitución del Reich o por las leyes federales, el Presidente del Reich puede exigirlas con ayuda de la fuerza armada». Relacionada con la citada disposición, el art. 48,3 de la citada Constitución establecía que «de las medidas adoptadas conforme a los arts. 1 y 2 de este artículo, se dará cuenta irrenunciablemente al Reichstag. Dichas medidas dejarán de estar en vigor a instancia del Reichstag».

6 Las medidas que el Estado central podía adoptar en sustitución de la actividad de los demás miembros del sistema descentralizado previstas en la época de la confederación — la denominada sequestratio- no fueron más recogidas en textos constitucionales posteriores. La sequestratio aparececía reconocida en el art. 19 
puestos teóricos y estructurales bien distintos a los del principio federal, lo que llevará a atribuir a la facultad de coerción estatal del art. 155 CE unos perfiles acusadamente propios. Tanto en lo que se refiere a la definición del supuesto de hecho como de sus consecuencias jurídicas. Además, el constituyente de 1978 ha optado por introducir en el supuesto de hecho de la coerción la cláusula relativa al «interés general (de España)» que resulta desconocida en la coerción federal.

La expresa alusión al «interés general de España», al que la doctrina ha vinculado a conductas procedentes de las CCAA que pongan en peligro el funcionamiento el Estado autonómico ${ }^{7}$, acaba orientando el discurso sobre del art. $155 \mathrm{CE}$ hacia lo que no es sino la plasmación de la norma de lealtad al principio autonómico. Esto distancia la función de la coerción estatal en el principio autonómico de la coerción federal cuyo enunciado, como se verá, no se construye a partir de la norma de lealtad, sino de la de sujeción. Es a partir de ahí, que el discurso sobre la coerción en el principio autonómico se separa del modelo de coerción federal. Seguidamente se verá con qué consecuencias.

\section{EL ART. 155 CE COMO PLASMACIÓN DEL PRINCIPIO DE LEALTAD AL ESTADO AUTONÓMICO}

Para poder determinar cuál es la función que está llamada a desempeñar el art. $155 \mathrm{CE}$ en la estructura del principio autonómico resulta necesario determi-

de la Verfassung des Norddeutschen Bundes de 1867: «La ejecución puede extenderse hasta la sequestratio del correspondiente Land y de sus facultades de gobierno». Conforme a lo reconocido por la literatura, la sequestratio podría ser total, traspasando todas las funciones de los Laender al Bund o parcial, de alguno de sus órganos, quedando el resto de órganos dentro de la capacidad de gobierno los Laender, véase E.-R. HubER, Deutsche Verfassungsgeschichte seit 1789, Band III —Bismark und das Reich-, Kohlhammer, Stuttgart y otros, 1988, p. 1041. Sin embargo, estas concretas medidas no aparecieron plasmadas en los textos constitucionales posteriores. Éstos, o bien autorizaron genéricamente la ejecución frente a los Länder (art. 19 de la Constitución de 1871), contemplando de manera puntual incluso el recurso a la fuerza armada (art. 48,1 de la Constitución de Weimar de 1919), o previeron la posibilidad de que el Estado central pudiera adoptar «las medidas necesarias» para garantizar el cumplimiento de las obligaciones impuestas a los Länder por la Constitución y las leyes federales (art. 37 de la Ley Fundamental de 1949). Esta controversia puede verse en los debates académicos suscitados en el ámbito de la Constitución del Reich alemán de 1871. Su art. 19 no determinaba expresamente el contenido de las medidas de ejecución: «Cuando uno de los miembros del Bund no cumpla con las obligaciones impuestas por la Constitución, pueden ser garantizadas por medio de la ejecución. Dicha ejecución es decidida por el Bundesrat y ejecutada por el Kaiser». Ciertas posiciones doctrinales han tratado de negar la validez de la categoría de la sequestratio de la confederación para poder interpretar el contenido de las medidas de ejecución, véase al respecto A. HäNEL, Deutsches Staatsrecht, Band I. Die Grundlagen des deutschen Staates und die Reichsgewalt, Dunker \& Humblot, Leipzig, 1892, p. 451. Por el contrario, favorable a importar la categoría de la sequestratio para interpretar el art. 19, bajo el argumento de que su enunciado no descarta expresamente dicha posibilidad, véase M. SEYdL, Commentar zur Verfassungs-Urkunde für das deutsche Reich, A. Stubers Buchhandlung, Würzburg, 1873, p. 137. Véase también al respecto del debate P. ZöRN, Das deutsche Staatsrecht, zweite völlig neu bearbeitete Auflage, F. Guttentag Verlagsbuchhandlung, Berlin SW, 1895, p. 140 .

7 Véase E. Vírgala Foruria, op. cit., p. 91. 
nar, antes de nada, cuál es el supuesto de hecho que faculta a los órganos previstos en aquella disposición a adoptar ciertas medidas contra las CCAA. A ello se refiere el art. $155 \mathrm{CE}$ al establecer: «si una Comunidad Autónoma no cumpliere las obligaciones que la Constitución u otras leyes le impongan, o actuare de forma que atente gravemente al interés general de España...». Como se ha tenido la oportunidad de poner de manifiesto, la literatura ha señalado la novedad que ha representado la inclusión de la cláusula relativa al «interés general de España» para definir el supuesto de hecho la coerción estatal en el principio autonómico respecto del art. 37 de la Ley Fundamental de Bonn, en el que se inspira ${ }^{8}$. En efecto, la coerción federal prevista en la citada disposición se limita a responder frente a la infracción de la «Constitución y de las leyes federales» por parte de los Länder. Como se verá, la cláusula relativa al «interés general de España» que se plasma en el art. 155 CE otorga a la coerción estatal en la CE de 1978 unos perfiles acusadamente propios.

\section{La distinción entre el incumplimiento de las normas de sujeción y de lealtad al principio autonómico}

La distinción expresamente realizada en el art. 155 CE entre el incumplimiento por parte de las CCAA de las obligaciones «que Constitución u otras leyes le impongan», de un lado, y el «atentado grave contra el interés general de España», de otro, es una consecuencia que se deriva de estructura que presenta el principio autonómico como resultado de su plasmación en una Constitución que se ha concebido como la norma suprema del ordenamiento jurídico. Una Constitución como norma jerárquicamente suprema, descentraliza territorialmente las funciones de creación y de aplicación de normas entre órganos, en el marco de determinadas competencias que han sido limitadas por la propia Constitución.

Cabe distinguir, por lo tanto, en el seno del principio autonómico del art. 2 CE, dos sistemas jurídicos parciales (el del Estado central y el de las CCAA) y un sistema jurídico soberano que confiere unidad a ambos sistemas (el Estado total) ${ }^{9}$. Esta estructura del Estado autonómico ha sido avalada por la jurisprudencia del $\mathrm{TC}^{10}$ y por

8 Véase ibídem., p. 79.

9 Véase sobre la teoría de los tres miembros del Estado federal, H. KELSEN, Allgemeine Staatslehre, Max Gehlen, Berlin, 1925, pp. 164 y ss.

10 STC 32/1981, FJ. 5. : «...en ocasiones (así, arts. 1, 56, 137 y en la propia rubrica de su Título VIII, por mencionar solo algunos ejemplos) el término Estado designa la totalidad de la organización jurídico-política de la Nación española, incluyendo las organizaciones propias de las nacionalidades y regiones que la integran y la de otros entes territoriales dotados de un grado inferior de autonomía; en otras, por el contrario (así, en los arts. 3.1, 149, 150), por Estado se entiende solo el conjunto de las instituciones generales o centrales y sus órganos periféricos, contraponiendo estas instituciones a las propias de las Comunidades Autónomas y otros, entes territoriales autónomos...» 
parte de la doctrina ${ }^{11}$. Esta estructura del sistema territorialmente descentralizado es la que justifica la doble sumisión jurídica que la CE impone, en general, a sus miembros a través de las normas de sujeción y de lealtad a diferentes contenidos del principio autonómico ${ }^{12}$. Estas normas, dirigidas a las CCAA, es posible identificarlas en el supuesto de hecho de la facultad de coerción estatal del art. 155 CE. Sin embargo, como se verá más adelante, los elementos estructurales del principio autonómico conducirán a diluir la norma de sujeción plasmada en el art. 155 CE en el contenido de la norma de lealtad, que ha de considerarse la única norma definitoria del supuesto de hecho del art. $155 \mathrm{CE}^{13}$.

La norma de sujeción en el enunciado del art. 155 CE se plasma en el mandato que se dirige a las CCAA para que cumplan las «obligaciones que la Constitución u otras leyes le impongan». Un mandato que tiene por objeto aquellas normas constitucionales y legales que, desarrollando el principio autonómico del art. 2 CE, fundamentan la existencia de los sistemas jurídicos parciales del Estado central y de las CCAA, y regulan los órganos, los procedimientos y las competencias sobre las que pueden actuar válidamente cada uno de dichos sujetos. Esa función la ejercen en la propia CE diferentes normas, entre ellas, los arts. 148, $149,152 \ldots$ Sin embargo, como consecuencia de la apertura del principio autonómico en el Título VIII, dicha función ha sido delegada por la CE —asumiendo un rasgo estructural diferenciador del principio federal- en ciertas normas dotadas de rango de ley.

Esas normas que ejercen una función materialmente constitucional son las que conforman el «bloque de la constitucionalidad»: los Estatutos de Autonomía (art. 147,1), las previstas en los arts. 150,1, 2 y 3 CE y las de delimitación com-

11 Véase, entre otros, I. Villaverde Menéndez, La igualdad en la diversidad. Forma de Estado y derechos fundamentales, CEPC, Madrid, 2012, pp. 39 y ss. Un trabajo monográfico orientado a tratar de justificar tanto en el texto constitucional de 1978, como en la jurisprudencia del TC, la teoría de los tres miembros del sistema territorialmente descentralizado puede consultarse en A. GARMENDIA MADARIAGA, «La posible plasmación de la teoría del tercer miembro del Estado federal en el ordenamiento jurídico español», Working Papers, n. ${ }^{\circ}$ 5, CEPC, 2011.

12 Véase sobre esta construcción L. Álvarez Álvarez, La lealtad constitucional en la Constitución Española de 1978, CEPC, Madrid, 2008, pp. 180 y ss. También «La función de la lealtad en Estado autonómico», Teoría y Realidad Constitucional, n. ${ }^{\circ} 22,2008$, pp. 493 y ss. Sin embargo, la vigente jurisprudencia del Tribunal Constitucional Federal ha negado la validez de teoría de los tres miembros del Estado federal para la concepción del sistema territorialmente descentralizado diseñado en la Ley Fundamental de Bonn de 1949, BVerfGE, 13, 54 (77). A pesar de ello, no ha sido óbice para poder construir en su propia jurisprudencia un principio de lealtad aplicable también al funcionamiento del Estado federal, BVerfGE. 1, 299 (315).

13 Una distinción similar entre sujeción y lealtad no fue posible identificarla el periodo de la confederación. La ausencia de Constitución como auténtica norma suprema impidió identificar en el sistema descentralizado una unidad jurídica superior al Estado «central» y a los demás Estados, que se concibieron como soberanos. Eso es lo que explica que la facultad atribuida a ciertos órganos para garantizar el cumplimiento por parte de los Estados de las obligaciones impuestas por la «Constitución» o por «la Constitución y las leyes»-Reichs /Bundesexekution - se construyera a partir de la idea de sujeción. Cfr. E.-R. HubER, Deutsche Verfassungsgeschichte seit 1789, Band I —Reform und Restauration 1789 bis 1830_, Kohlhammer, Stuttgart, 1960, pp. 635 y ss., M. SEYDL, op. cit., p. 136. 
petencial (arts. 148,1, 22. $\left..^{\circ}, 149,1,29 .^{\circ}, 152,1\right)^{14}$. Esta sujeción a las normas formal y materialmente constitucionales que confieren validez a los sistemas jurídicos parciales del Estado central y las CCAA quizás sea el contenido constitucionalmente más adecuado del deber dirigido a las CCAA en el art. 155 CE para que cumplan «las obligaciones que la Constitución u otras leyes le impongan» ${ }^{15}$. Esta definición del concepto de «leyes» en el art. $155 \mathrm{CE}$ a partir de la estructura que presenta el principio autonómico pone de manifiesto otra diferencia con el modelo de coerción federal alemán que identifica las «leyes» con las «leyes federales» (art. 37 de la Ley Fundamental). Mientras la facultad de coerción del art. 155 CE sirve a la garantía de normas pertenecientes al Estado total ${ }^{16}$, esto es, a las normas que tienen como función definir la posición de todos los sujetos del Estado autonómico, en el caso de la coerción federal, ésta tiene por objeto, en parte, normas del Estado central. Más adelante se verá qué incidencia tiene esta concepción del objeto del art. $155 \mathrm{CE}$ sobre su particular función en la estructura del principio autonómico.

Un ejemplo de la constatación de la infracción de la norma de sujeción de las CCAA al principio autonómico_-aunque sin invocación del art. 155 CE-aparece en la STC 31/2015, que resolvió el recurso de inconstitucionalidad interpuesto por el Presidente del Gobierno contra la Ley del Parlamento de Cataluña 10/2014, de consultas populares no refrendarias y otras formas de participación ciudadana. El TC afirmó que la citada ley constituía una infracción de la sujeción constitucionalmente debida a las normas de la Constitución y del bloque de la constitucionalidad que ejercen la función de distribuir competencias entre el Estado central y las CCAA, en particular, del art. $149,1,32 .^{\circ} \mathrm{CE}$, que confiere en régimen de exclusividad al Estado central la competencia sobre la «autorización para la convocatoria de consultas populares por vía de referéndum»: «En efecto, los conceptos constitucionales o, en general, del bloque de la constitucionalidad que definen o acotan competencias (el de «referéndum» ex art. 149.1.32 CE, en lo que ahora importa) resultarían distorsionados, y con ellos la misma articulación competencial, si su propia definición se hiciera depender del respeto o transgresión, por el Estado o por las Comunidades Autónomas, de la legalidad, constitucional o infraconstitucional, a la que en cada caso se encuentran sometidos» (FJ. 6. ${ }^{\circ}$.

14 Véase acerca de la función de tales normas P. REQUEjo RodRíGuEz, Bloque constitucional y bloque de la constitucionalidad, Servicio de Publicaciones de la Universidad de Oviedo, Oviedo, 1997, p. 47 y ss. Esta interpretación ha sido mantenida para definir el objeto del art. 155 CE por X. BALLART, Coerciò estatal $i$ autonomies. L'article 155 de la Constituciò de 1978, Escola d'Administració Pública de Catalunya, Barcelona, 1987, pp. 126 y 127.

15 En la doctrina española no han faltado posiciones que han tratado de englobar en el concepto de «otras leyes», también leyes aprobadas del Estado central, e incluso de las CCAA. Véase E. Vírgala ForuRIA, op. cit., pp. 86 y 87, J. García Torres, op. cit., p. 1257.

16 Cfr. H. Kelsen, «Die Bundesexekution» en Z. Giacometti y D. Schindler (edits.), Festgabe für Fritz Fleiner zum 60 Geburtstag, JCB Mohr, Siebeck, 1927, pp. 129, 136. 
Esta norma de sujeción cabe distinguirla en el art. 155 CE de la norma de lealtad que se deriva de la prohibición de atentar «contra el interés general de España ${ }^{17}$. Con ella, se impone una sumisión a las normas constitucionales que ejercen la función de conferir unidad a los sistemas jurídicos parciales del Estado central y de las CCAA. En concreto, las que definen el contenido nuclear del principio autonómico del art. 2 CE, objeto de la norma de lealtad ${ }^{18}$. De acuerdo con ello, la norma de lealtad del art. 155 CE no resultaría vulnerada por el mero hecho de que las CCAA se extralimitaran de sus competencias, sino por las conductas que, por su reiteración o por su gravedad, sean idóneas para afectar a la eficacia del principio autonómico del art. 2 CE, esto es, al correcto funcionamiento del mismo. Esta interpretación de la noción «interés general de España» del art. 155 CE en el sentido de un deber (de lealtad) al servicio de la eficacia del principio autonómico queda avalada en el texto constitucional, cuyo art. 150,3 CE autoriza a las Cortes Generales a aprobar leyes de armonización cuando así lo exija «el interés general». Un concepto que, tanto la jurisprudencia del $\mathrm{TC}^{19}$ como la doctrina ${ }^{20}$, han vinculado al eficaz funcionamiento principio autonómico.

Un ejemplo de la constatación de la infracción de la norma de lealtad a este principio - aunque sin invocar el art. 155 CE_- aparece en la STC 259/2015, que resolvió la impugnación realizada por el Gobierno contra la resolución del Parlamento de Cataluña 1/XI, de 9 de noviembre de 2015, «sobre el inicio del proceso político en Cataluña como consecuencia de los resultados electorales del 27 de septiembre de 2015». Para el TC, la citada resolución no constituye una mera infracción de la CE, sino un manifiesto desconocimiento de su normatividad, que pone en peligro su eficacia misma como norma suprema del sistema territorialmente descentralizado: «Se trata de una infracción constitucional que no es fruto, como suele ocurrir en las contravenciones de la norma fundamental, de un entendimiento equivocado de lo que la misma impone o permite en cada caso. Es resultado, más bien, de un expreso rechazo a la fuerza de obligar de la Constitución misma... se trata de la afirmación de un poder que se pretende fundante de un nuevo orden político y liberado, por ello mismo, de toda atadura jurídica» $\left(\mathrm{FJ} .6^{\circ}\right)^{21}$.

17 Esta vinculación del interés general con el principio de lealtad al principio autonómico, ha sido señalada por la doctrina. Véase E. Vírgala Foruria, op. cit., pp. 91 y 93. En similares términos, J. García Torres, op. cit., p. 1268. Más recientemente E. GonZÁlez HernándeZ, «El artículo 155 y la LO 15/2015, de 17 de octubre de reforma de la LOTC: ¿ineludible reciprocidad o círculo perverso?, Teoría y Realidad Constitucional, n. ${ }^{\circ} 37,2016$, pp. 539 y ss.

18 L. Álvarez Álvarez, La lealtad constitucional en la Constitución Española de 1978, op. cit., p. 15.

19 STC 76/1983, FJ. 3.․

20 Véase P. REQUEjo RodRíguez, «La resurrección del interés general en el Estado autonómico», Revista de Derecho Político, n. ${ }^{\circ} 87,2013$, p. 171.

21 La citada sentencia reitera la doctrina emitida en la STC 103/2008, en la que afirmó que «tratar de sortear, eludir o simplemente prescindir de esos procedimientos sería intentar una inaceptable vía de hecho 
En definitiva y, sin perjuicio de ulteriores consideraciones, cabe afirmar que el art. $155 \mathrm{CE}$ autoriza el ejercicio de la coerción estatal en dos supuestos vinculados con la estructura del principio autonómico: 1) cuando las CCAA incumplan las normas de la Constitución y de las leyes del bloque de la constitucionalidad que regulan los órganos, los procedimientos y las competencias sobre las que pueden válidamente actuar el Estado y las CCAA —norma de sujeción-y 2) en el caso de que las CCAA pongan en peligro la eficacia de aquellas normas constitucionales que confieren unidad a los sistemas jurídicos parciales del Estado y de las CCAA —norma de lealtad ${ }^{22}$.

\section{El carácter extraordinario del art. 155 CE y la disolución de la norma de sujeción en la de lealtad}

La literatura ha aceptado de forma mayoritaria el carácter excepcional de la facultad prevista en el art. $155 \mathrm{CE}^{23}$. También el TC que, en su escasa jurisprudencia emitida sobre el art. $155 \mathrm{CE}$, lo ha calificado como «un mecanismo extraordinario de coerción» (STC 49/1988, FJ. 31. ${ }^{\circ}$ ). Ha de reconocerse, sin embargo, que en la tradición del sistema territorialmente descentralizado la atribución a determinados órganos del Estado «central» de la facultad para obligar al cumplimiento de las obligaciones al resto de sus miembros no presentó en todos los supuestos un carácter excepcional. No lo fue, en primer lugar, cuando sirvió para suplir las deficiencias de la justicia constitucional. Bien garantizando el control jurídico de conflictos ${ }^{24} \mathrm{o}$

(incompatible con el Estado social y democrático de Derecho que se proclama en el art. 1.1 CE) para reformar la Constitución al margen de ella o conseguir su ineficacia práctica» (FJ. 4..$^{\circ}$ ).

22 Parte de la doctrina ha negado, sin embargo, que el art. 155 CE permita llevar a cabo un control jurídico sobre la actividad de las CCAA. Se trataría de un control de discrecionalidad política. En ese sentido se han manifestado O. Alzaga Villaamil, Comentario sistemático a la Constitución Española de 1978, Foro, Madrid, 1978, pp. 890 y ss. L. Tolivar Alas, El control del Estado sobre las Comunidades Autónomas, Instituto de Estudios de Administración Local, Madrid, 1981, p. 186.

23 Véase ejemplificativamente X. Ballart, op. cit., p. 125, V. Calafell Ferrá, «Compulsión o coerción estatal (Estudio del art. 155 de la Constitución Española)», Revista de Derecho Político, n. ${ }^{\circ}$ 48-49, 2000, p. 11. Contrario a la excepcionalidad del art. 155 CE se manifiesta J. GARCía TORREs, op. cit., pp. 1224 y ss.

24 Esa ha sido la función atribuida a la ejecución estatal en la Constitución del Reich de 1871, plasmada en su art. 19: «si alguno de los miembros del Estado descentralizado no cumple con las obligaciones impuestas por la Constitución, pueden ser exigidas por medio de la ejecución. La ejecución es decidida por el Bundesrath y ejecutada por el Kaiser». En la citada Constitución, el Bundesrath se concibió como el órgano competente para resolver controversias jurídicas no atribuidas al conocimiento de los tribunales de justicia (véanse los arts. 7,3 y 76). El texto constitucional atribuía a éstos la resolución de los conflictos jurídicos que se suscitaran dentro de los diferentes Estados como entre éstos entre sí, véase E.-R. HubER, op. cit., pp. 1066 y ss. Por ello, las controversias suscitadas entre los Länder y el Reich sobre el adecuado cumplimiento de la Constitución o de las leyes recaía en el ámbito competencial del Bundesrath (art. 7,3) pudiendo, en el caso de que se constatara tal incumplimiento, decidir sobre la ejecución estatal contra los Länder en los términos previstos en el art. 19. Se discutió, sin embargo, en la doctrina, si el Bundesrath debía abrir necesariamente un procedimiento destinado a constatar tal infracción, como el previsto en el art. 7,3, antes de decidir sobre el 
de normas ${ }^{25}$ que excedía de la competencia de los tribunales de justicia, bien cuando sirvió para garantizar la ejecución de resoluciones judiciales, dotadas de un carácter declarativo ${ }^{26}$. Pero tampoco lo fue, en segundo lugar, cuando la coerción federal sirvió para asegurar la eficaz ejecución de las «leyes» de la federación por parte del resto de los miembros del sistema descentralizado, tal como sucede también hoy, en parte, con el modelo de coerción federal plasmado en la Ley Fundamental $^{27}$. Como se puede ver, en estos casos, la coerción estatal no sirve a la garantía del Estado total, esto es, a las normas constitucionales que confieren unidad a los sistemas jurídicos parciales que lo integran, sino más bien a las normas aprobadas por uno de sus miembros: el Estado central. En parte por ello, la jurisprudencia del Tribunal Constitucional Federal alemán ha negado un carácter extraordinario a la coerción federal del art. 37 de la Ley Fundamental ${ }^{28}$.

Sin embargo, una facultad de coerción como la prevista en el art. $155 \mathrm{CE}$ que vincula a los sujetos del sistema territorialmente descentralizado a través de normas de sujeción y lealtad al servicio de normas que pertenecen al Estado total, cuyo control jurídico se atribuye plenamente a un TC, el art. 155 CE ha

ejercicio de la ejecución estatal del art. 19, o si, por el contrario, podía recurrir directamente al art. 19. Véase al respecto M. Seydl, op. cit., p. 137.

25 Ese fue el caso del denominado «derecho constitucional no escrito», naturaleza del que gozaba el principio de lealtad federal. Véase sobre dicha construcción de la ejecución estatal durante la época de la Constitución de Weimar de 1919, G. Anschütz, «Die Reichsexekution» en G. Anschütz y R. ThомA (edits.), Handbuch des Deutschen Staatsrechts. Band I, Mohr, Siebeck, 1930, p. 378.

26 Ello derivó en un modelo de ejecución estatal como ejecución de decisiones judiciales que se plasmó en el art. 19 de la Constitución de Weimar de 1919: «El Presidente del Reich ejecutará la decisión del Staatsgerichthof» (art. 19,2). Y así, Heinrich Triepel afirmó que en el caso de que el Staatsgerichthof impusiera judicialmente al Reich, como consecuencia de un conflicto planteado entre el Reich y los Länder (art. 19, par. 1) la derogación de una ley, el Reichspräsident debía, a través de la facultad de ejecución de las sentencias del Statsgerichtshof (art. 19, par. 2), proceder a su supresión, véase del citado autor «Streitigkeiten zwischen Reich und Länder. Beiträge zur Auslegung des Artikels 19 der Weimarer Reichsverfassung» en Juristische Fakultät Berlin (edit.), Festgabe der Berliner Juristischen Fakultät für Wilhelm Kabl, JCB Mohr, Tübingen, 1923, p. 111. En el mismo sentido, H. PöHL, «Die Zuständigkeiten des Reichspräsidenten» en G. Anschütz y R. Thoma (edits.), Handbuch des Deutschen Staatsrechts, Band I, op. cit., p. 499. En contra de esta opinión se manifestó Anschütz, afirmando que las resoluciones del Staatsgerichtshof que impusieran, en particular, la supresión de una ley del Reich son «inejecutables». Véase Die Verfassung des Deutschen Reiches vom 11. August 1919. Ein Kommentar für wissenschaft und Praxis, Scientia (Neudruck der 14 Auflage, Berlin 1933), Aalen, 1987, pp. 174 y 175. También, en contra de la posibilidad de que el Reichspräsident pudiera proceder a la ejecución de las sentencias del Staatsgerichtshof contra el propio Reich, véase H. KELSEN, «Die Bundesexekution», op. cit., pp. 172 y 173 .

27 Sin perjuicio de que más adelante se hablará sobre ello, véase para este modelo en la Constitución de Weimar de 1919, H. KELSEN, «Die Bundesexekution», op. cit., pp. 136 y ss. En lo que se refiere a la vigente Ley Fundamental de Bonn de 1949, véase W. BLÜMEL, «Verwaltungszuständigkeit» en J. IsENSEE y P. KIrChHOFf (edits.), Handbuch des Staatsrechts. Band IV — Finanzverfassung — Bundesstaatliche Ordnung —, CH Beck, Heidelberg, 1990, pp. 899 y 900.

28 BVerfGEE. 3, 52 (57), 7, 367(372). En la doctrina, negando el carácter excepcional del art. 37, véase K. Stern, Das Staatsrecht der Bundesrepublik Deutschland, Band I, ed. CH. Beck, 1977, p. 560. Por su parte, posiciones favorables a considerar la facultad de coerción federal como excepcional, véase I. von Münch, Grundgesetz, CH. Beck, München, 1976, p. 373, A. PfeIffer, «Der Bund und die Länder», Die Öffentliche Verwaltung, n. ${ }^{\circ} 2,1949,263,265$. 
de considerarse como una facultad extraordinaria. El carácter extraordinario del art. $155 \mathrm{CE}$ posee una importante incidencia en lo que se refiere a la adecuada interpretación de su supuesto de hecho. El carácter extraordinario de la facultad del art. $155 \mathrm{CE}$ acaba por diluir el contenido de la norma de sujeción en la de lealtad.

En efecto, si se parte del carácter extraordinario del art. 155 CE parece claro que hay que concluir que la simple infracción por parte de las CCAA de las normas de la «Constitución y de las leyes» no bastaría para aplicar el mecanismo previsto el art. $155 \mathrm{CE}$. El carácter extraordinario del art. $155 \mathrm{CE}$ tendría que conducir a exigir una infracción bien cuantitativa bien cualitativa de la «Constitución y de las leyes» que ejercen la función de regular los órganos, los procedimientos y las competencias sobre las que pueden actuar válidamente el Estado y las CCAA para poder ejercer la facultad de coerción estatal ${ }^{29}$. Algo que acaba por diluir el contenido de la norma de sujeción en el de la norma de lealtad, ya que la reiteración o la gravedad exigible en aquella infracción de la «Constitución y de las leyes» acabaría por afectar a la eficacia misma del principio autonómico del art. 2 CE, esto es, al «interés general de España».

En consecuencia, hay que acabar concluyendo que el art. $155 \mathrm{CE}$ constituye la plasmación de la norma de lealtad al principio autonómico y su infracción es la que legitima el ejercicio de la facultad de coerción ${ }^{30}$. Sin embargo, ello no debe de conducir a pensar que la expresa plasmación de una norma de sujeción en el enunciado del art. $155 \mathrm{CE}$ carece de sentido, como consecuencia de su disolución en la norma de lealtad. La expresa plasmación de esta obligación (parcial) de sujeción de las CCAA en el art. 155 CE-por oposición al genérico recogido en el art. 9,1 CE—sirve para delimitar qué infracción reiterada o grave de qué concretas normas puede conducir a entender vulnerada la norma de lealtad del art. 155: las de la $\mathrm{CE}$ y el bloque de la constitucionalidad que regulan órganos, procedimientos y competencias entre el Estado central y las CCAA.

29 Cfr. Vírgala Foruria, op. cit., p. 89.

30 Parte de la doctrina ha acabado llegando a la consecuencia contraria: a diluir la norma de lealtad en la de sujeción, que sería la única que definiría el supuesto de hecho del art. 155 CE. Para llegar a esta conclusión se parte de que no cabe identificar, efectivamente, un atentado al «interés general de España», que no suponga una infracción de la Constitución o de la ley. Esta consecuencia acaba por identificar el supuesto de hecho de la coerción en el principio autonómico y la coerción federal. Véase, entre otros, E. AlberTi Rovira, op. cit., p. 473 y X. BALlART, op. cit., p. 138. El problema es que estas posiciones no son capaces de explicar la expresa plasmación del interés general de España en el enunciado del art. $155 \mathrm{CE}$ que, como se ha puesto de manifiesto, puede ser entendida como la plasmación de la norma de lealtad al principio autonómico. Sin embargo, por su parte Vírgala mantiene la dualidad de supuestos de hecho, sin que el incumplimiento de la Constitución y de las leyes se confunda con el atentado contra el interés general de España. Esta dualidad de supuestos de hecho conducirá, a juicio del citado autor, a distinguir el tipo de medidas que cabe activar contra las CCAA (véase op. cit., p. 99). De todos modos, si, como mantiene el citado autor, el incumplimiento de las obligaciones constitucionales y legales ha de ser grave (p. 89), habría buenas razones para mantener que dicho incumplimiento acaba suponiendo un atentado contra el interés general de España, tal y como aquí se ha tratado de mantener. 
En realidad, la CE pretende responder a través del art. $155 \mathrm{CE}$ frente a las conductas de las CCAA que vulneren de forma reiterada o grave el marco normativo que define su inserción en el sistema unitario ${ }^{31}$. Tales conductas son quizás las que con mayor intensidad pueden poner en peligro el funcionamiento mismo del principio autonómico por oposición a otras frente a las que cabe reaccionar a través de otro tipo de mecanismos previstos en el ordenamiento jurídico. Suscitado el debate en términos de idoneidad para poder vulnerar la eficacia del principio autonómico, parece que también ha de concluirse que las conductas de las CCAA a las que se refiere el art. $155 \mathrm{CE}$ son aquellas que proceden de sus órganos superiores $^{32}$.

Como ya se tuvo la oportunidad de avanzar con anterioridad, la STC 259/2015 constató una infracción de las normas de sujeción en el modo previsto en el art. $155 \mathrm{CE}$ al declarar la inconstitucionalidad de la resolución del Parlamento de Cataluña 1/XI, de 9 de noviembre de 2015, «sobre el inicio del proceso político en Cataluña como consecuencia de los resultados electorales del 27 de septiembre de 2015». El TC afirma que: «El Parlamento de Cataluña ha optado por aprobar, a través del procedimiento parlamentario propio de las propuestas de resolución, la Resolución 1/XI, cuyo contenido incide directamente, como ya se ha puesto de manifiesto, sobre cuestiones reservadas en su tratamiento institucional al procedimiento de reforma constitucional del artículo $168 \mathrm{CE}$ ( $\left.\mathrm{FJ} .7 .{ }^{\circ}\right)$.

Sin embargo, para el TC, la Resolución del Parlamento de Cataluña 1/XI, no implica solo una infracción competencial, sino que el incumplimiento de la norma de sujeción adquiere un carácter especialmente cualificado porque «Es resultado, más bien, de un expreso rechazo a la fuerza de obligar de la Constitución misma... de la afirmación de un poder que se pretende fundante de un nuevo orden político y liberado, por ello mismo, de toda atadura jurídica» (FJ. 6. ${ }^{\circ}$ ). Es decir, se acredita un incumplimiento cualificado de la norma de sujeción que lesiona la norma de lealtad al principio autonómico, lo que configuraría el supuesto de hecho del art. $155 \mathrm{CE}$.

De igual modo, el supuesto de hecho del art. 155 CE también puede quedar acreditado en el caso de que exista una infracción de las normas de la CE y del bloque de la constitucionalidad, no cualitativa, sino cuantitativamente relevante. Así, la STC 31/2015 ya aludida, acreditó la infracción de la norma de sujeción a la Constitución y las leyes del bloque de la constitucionalidad por parte de la Ley del Parlamento de Cataluña de consultas populares no refrendarias y otras formas de participación, sin que se haya constatado una infracción cualificada del principio autonómico. Probablemente tal infracción de la sujeción no sea por sí misma adecuada para vulnerar la norma de lealtad. Sin embargo, el TC ha acreditado sucesivas infracciones por parte de Cataluña de similares normas de la CE y del 
bloque de la constitucionalidad, que podrían conducir a que se alcance esa infracción de la norma de lealtad.

Piénsese en la STC 32/2015, que declaró inconstitucional, por los mismos motivos, el Decreto 129/2014, del Presidente de la Generalitat, de convocatoria de la consulta no referendaria sobre el futuro político de Cataluña, también en la STC 138/2015, que declaró inconstitucionales las actuaciones de la Generalitat de Cataluña relativas a la convocatoria a los catalanes, las catalanas y las personas residentes en Cataluña para que manifiesten su opinión sobre el futuro político de Cataluña. En definitiva, declarada la inconstitucionalidad de la ley, del decreto que convoca la consulta y de las actuaciones orientadas a su celebración, se puede llegar a un punto que refleje una infracción cuantitativa de la Constitución y del bloque de la constitucionalidad que podría considerarse que puede acabar afectando a la eficacia del principio autonómico, cumpliendo el supuesto de hecho del art. $155 \mathrm{CE}$.

Sin embargo, como se verá más adelante al hablar de la función que cumple el art. $155 \mathrm{CE}$ en el entramado del principio autonómico, no toda conducta que satisfaga el supuesto de hecho del art. 155 CE legitimará automáticamente la adopción las «medidas necesarias» a las que se refiere dicha disposición. Entre otras cosas, porque tales medidas, dado el carácter extraordinario de la coerción estatal, sirven para reaccionar frente una muy concreta tipología de infracciones de la norma de lealtad: aquéllas ante las que la jurisdicción constitucional no puede responder eficazmente.

\section{LA FUNCIÓN DEL ART. 155 CE EN LA ESTRUCTURA DEL PRINCIPIO AUTONÓMICO. COERCIÓN ESTATAL Y JURISDICCIÓN CONSTITUCIONAL}

\section{La coerción estatal como función del Estado total}

La estructura del principio autonómico, además de legitimar desde un punto de vista teórico la doble vinculación jurídicamente impuesta a sus normas dirigida a los sujetos del sistema descentralizado (lealtad y sujeción), permite distinguir dos tipos de funciones que contribuirán a dotar de sentido al art. 155 CE. El principio autonómico distingue, de un lado, la función consistente en crear y aplicar normas en el marco de un régimen orgánico, procedimental y competencial limitado. Esta es la función que ejercen los órganos del Estado y de las CCAA, como se ha visto, con sujeción a las normas de la Constitución y de las leyes del bloque de la constitucionalidad que establecen las condiciones de validez de sus respectivos sistemas jurídicos parciales.

De otro lado, el principio autonómico también distingue la función consistente en crear y aplicar el régimen jurídico al que tanto el Estado central como las CCAA han de sujetarse obligatoriamente, propia del Estado total. Esa función 
es la que ejercen las Cortes Generales cuando reforman el principio autonómico del art. 2 CE mediante el procedimiento de reforma constitucional del art. 168 $\mathrm{CE}-\mathrm{y}$ en ciertos casos incluso por el del art. $167 \mathrm{CE}$ - También cuando, por remisión de la propia CE, crean las leyes que integran el bloque de la constitucionalidad: los Estatutos de Autonomía, las leyes del art. 150 CE y las leyes de delimitación competencial.

En estos casos, las Cortes Generales ejercen una función del Estado total, creando el régimen jurídico al que han de someterse los órganos de las CCAA y los órganos del Estado central, cuya actuación solo resulta válida dentro de aquél. También las propias Cortes Generales cuando actúan sujetas al sistema competencial diseñado por la CE y por las leyes del bloque de la constitucionalidad. Esta función del Estado total también la ejercen en el principio autonómico los órganos jurisdiccionales a los que alude el art. $153 \mathrm{CE}$ y a los que se les atribuye el control de la actividad de las CCAA: el TC, el Tribunal de Cuentas y la jurisdicción de lo contencioso-administrativo. Ejercen esa función cuando aplican frente al Estado central y las CCAA el régimen jurídico que define su encaje en el sistema unitario.

En el marco de la distinción de estas dos funciones, es donde resulta necesario plantearse si el art. $155 \mathrm{CE}$ se define como una función del Estado central o del Estado total. De mantener la primera opción, tendría que afirmarse que los órganos previstos en el art. 155 CE deberían de actuar con plena sujeción al régimen jurídico previsto en la CE y en bloque de la constitucionalidad. Habría que descartarse, por tanto, que los órganos a los que se refiere el art. 155 CE (el Gobierno y, en su caso, el Senado) pudieran interferir en el ámbito competencial propio de las CCAA, debiendo circunscribirse a adoptar medidas que la CE y el bloque constitucional atribuyen a los órganos del Estado central ${ }^{33}$. Esto sería

33 Una concepción de la coerción estatal como una función propia del Estado central es la que ha mantenido un determinado modo de proceder a su construcción en el sistema territorialmente descentralizado. Este modelo de coerción federal la concibe como una medida al servicio de la eficaz ejecución de las leyes del Estado central por parte de los Länder. En base a esta construcción, el Estado central puede actuar de manera sustitutiva en caso de una inadecuada ejecución de las leyes aprobadas por la Federación. Sin embargo, en lo que aquí interesa, el Estado central no actúa ejerciendo una función propia del Estado total, sino una competencia del Estado central. El art. 7 de la Constitución de Weimar de 1919 determinaba que «las leyes federales son ejecutadas por las autoridades de los Länder, en tanto las leyes federales no dispongan otra cosa», de manera similar a lo que regula el vigente art. 85 de la Ley Fundamental de 1949, relativo a «la ejecución de las leyes federales por los Länder por delegación de la Federación». Como se puede ver, corresponde a la Federación la competencia sobre la legislación y también sobre la ejecución de sus propias leyes, si bien esta ha sido descentralizada territorialmente en los Länder. Siendo esto así, cuando se reconoce que, por medio de la coerción federal, la Federación puede sustituir a los Länder en caso de una inadecuada ejecución de las leyes estatales, aquélla no está interfiriendo en el ámbito competencial de los Länder, sino ejerciendo una competencia propia, es decir, del Estado central. La coerción estatal opera aquí como una norma de «devolución competencial» conforme a la que el ejercicio de la competencia en materia de ejecución de leyes estatales, retorna a la Federación, su verdadero titular. Como se puede ver, este modelo de coerción se construye a partir de la idea de competencias concurrentes, considerándose aquél como la plasmación del principio de prevalencia (Bundesrecht bricht Landesrecht), cfr. H. KELSEN, «Die Bundesexekution», op. cit., p. 180. Solo por ello, este 
compatible con la concepción del art. 155 CE como un mecanismo (de presión) orientado a conminar a que las CCAA cumplan (por sí mismas) la lealtad al principio autonómico. Esa es la finalidad que comparte una de las medidas que tradicionalmente se han englobado en la facultad de coerción en el sistema territorialmente descentralizado, las medidas de presión financiera ${ }^{34}$, que se han afirmado para la interpretación del art. 155 CE: la suspensión de transferencias en curso a las CCAA o suspensión de la participación de éstas en los ingresos del Estado ${ }^{35}$.

La concepción del art. $155 \mathrm{CE}$ como una medida de presión para garantizar el cumplimiento de la lealtad al principio autonómico, que tendría que llevarse a cabo por parte de la propia CCAA, es lo que pareciera sugerir a primera vista la literalidad del enunciado del art. 155 que afirma que se podrán «adoptar las medidas necesarias para obligar a aquélla al cumplimiento forzoso de dichas obligaciones ${ }^{36}$. Sin embargo, si se entendiera que el art. 155 CE simplemente autorizaría al Estado a forzar a las CCAA a que cumplan con su deber de lealtad al principio autonómico ejerciendo facultades que ya le reconoce la $\mathrm{CE}$, la expresa plasmación del art. $155 \mathrm{CE}$ carecería de sentido ${ }^{37}$.

La previsión constitucional de una disposición como la consagrada en el art. $155 \mathrm{CE}$ puede explicarse si la misma se considera como la plasmación de una función del Estado total, esto es, como una facultad para crear y aplicar el régimen jurídico al que los integrantes del Estado autonómico han de someterse imperativamente. Ello permitiría a los órganos a los que se refiere el art. $155 \mathrm{CE}$ trascender del reparto competencial diseñado por la CE y el bloque de la constitucionalidad, e interferir, como órganos del Estado total, en el ámbito competencial propio de las $\mathrm{CCAA}^{38}$. La simple lectura del art. 155,2 CE parece tener que conducir a dicha posibilidad, al afirmar que «para la ejecución de las medidas previstas en el apartado anterior, el Gobierno podrá dar instrucciones a todas las autoridades de las Comunidades Autónomas».

La concepción del art. 155 CE como una función del Estado total cabe inferirse de su objeto y de la naturaleza de los órganos a los que se les atribuye el ejercicio de la facultad de coerción. En lo que se refiere a su objeto, el art. $155 \mathrm{CE}$ no se propone la tutela de una norma perteneciente a los sistemas jurídicos par-

modelo de coerción tiene que descartarse en el seno de la Constitución Española de 1978. A pesar de que ha plasmado de manera expresa el principio de prevalencia del derecho del Estado en el art. 149,3 CE, la regla de residualidad prevista en la citada disposición que determina que todo lo no asumido por las CCAA corresponde al Estado, le priva de contenido.

34 Véase H. Klein, «Artikel 37» en T. Maunz y G. Dürig (edits.), Grundgesetz Kommentar, CH. Beck, München (hojas intercambiables, ed. 2010).

35 Véase entre otros E. Vírgala Foruria, op. cit., p. 101, V. Calafell Ferrá, op. cit., p. 131.

36 La cursiva es del autor.

37 Por ejemplo, proceder a la derogación de las leyes del art. 150,1 y 2 CE, recobrando las competencias que han sido previamente transferidas o delegadas a las CCAA. La posibilidad de recurrir a este mecanismo de «presión» ya aparece reconocido en el art. 150, sin necesidad de apoyarlo en el art. 155 CE.

38 Esta posición ha sido compartida de manera generalizada en la doctrina, véase entre otros E. ALBERTí ROvira, op. cit., p. 473 
ciales del Estado central o de las CCAA, algo que sucede con el modelo de coerción federal, que opera como un instrumento al servicio de la ejecución de las leyes de la federación. El art. $155 \mathrm{CE}$ tiene por objeto una norma constitucional del Estado total —el contenido nuclear del principio autonómico- que sirve a dotar de unidad a los sistemas jurídicos parciales del Estado central y de las CCAA. Si, como se ha reconocido, ningún sistema descentralizado puede funcionar de una forma eficaz sin la lealtad de sus miembros a los principios básicos que lo organizan ${ }^{39}$, la garantía (última) de la norma de lealtad al principio autonómico que se plasma en el art. 155 — sobre lo que se tratará más adelante— ha de considerarse como una función del Estado total.

Esto se encuentra reforzado además por otro elemento definitorio de la estructura del principio autonómico y que lo opone al principio federal. El principio de unidad del Estado federal surge como resultado de la voluntad de los sujetos del sistema territorialmente descentralizado, cuya existencia es previa a aquélla. Siendo esto así, el Estado federal puede presuponer teóricamente en su funcionamiento la lealtad de sus miembros a la unidad y construir la facultad de coerción estatal a partir de la idea de sujeción. Esto es lo que sucede, como se ha visto, en el art. 37 de la Ley Fundamental ${ }^{40}$.

Sin embargo, este presupuesto no rige en el caso del principio autonómico de la $\mathrm{CE}$, que autoriza una descentralización territorial a partir de la existencia de una unidad jurídica previa. De acuerdo con ello, puede resultar coherente que la CE, al tiempo que autoriza a ciertos órganos - las Cortes Generales- a ejercer una función del Estado total aprobando las leyes del bloque de la constitucionalidad que llevan a cabo la descentralización a partir de la unidad, retenga mediante la facultad del art. 155 CE la garantía de la eficacia última de la unidad del Estado autonómico. Si aquella primera regula una función del Estado total, la prevista en el art. $155 \mathrm{CE}$, que controla la garantía de la lealtad a la unidad, tiene que tener la misma naturaleza.

39 Véase K. Hesse, Grundzüge des Verfassungsrechts der Bundesrepublik Deutschland, CF. Müller, Heidelberg, 1990, p. 110, K. STERn, op. cit., p. 546 y H. W BAYER, Die Bundestreue, JCB Mohr, Tübingen, 1961, p. 43.

40 A pesar de que los sucesivos textos constitucionales han reproducido los enunciados propios de la ejecución en la confederación, la paulatina federalización del Estado ha propiciado algún intento en la literatura de tratar de vincular desde un punto de vista teórico la ejecución estatal a una lealtad a la unidad del sistema territorialmente descentralizado. Así ha sucedido en el contexto de la Constitución del Reich de 1871, Max Seydl, que afirmó que la ejecución estatal no tiene como función asegurar el cumplimiento del deber de «obediencia», sino el de lealtad por parte de los Länder, op. cit., p. 136. Sin embargo, lo cuestionable de esta construcción es que, a pesar de que en la literatura fue objeto de discusión si el Reich tenía la consideración de una confederación de Estados o de un Estado federal, el citado autor se decantó por concebir al Reich como una confederación (idem., pp. 3 y ss.), lo que, como se ha visto, conduce a consecuencias estructurales para la concepción del sistema descentralizado, difícilmente compatibles con la concepción de la Reichsexekution como la reacción a una deslealtad de los Länder. Por su parte, posiciones más favorables a considerar al Reich como un Estado federal, P. LABAnd, Das Staatsrecht des deutschen Reiches, Band I, JCB Mohr, Freiburg/ Leipzig, 1895, pp. 80 y ss. Por su parte, en el vigente derecho constitucional alemán, vinculando la ejecución estatal con la garantía de una norma de lealtad al principio federal, véase M. Bullinger, «Zum Verhälnis von Bundesaufsicht und Bundestreue», Archiv des Öffentlichen Rechts, n. ${ }^{\circ} 87,1962$, pp. 495 y ss. 
Esta concepción del art. 155 CE como una función del Estado total se ve reforzada, además, por el hecho de que en la decisión sobre el ejercicio de la coerción estatal participen todos los sujetos del principio autonómico. Como dispone el art. 155 CE, el ejercicio de la coerción se atribuye al Gobierno y, en caso de que su requerimiento no sea atendido voluntariamente por las CCAA, con la aprobación por la mayoría absoluta del Senado. El Gobierno participa en el procedimiento del art. $155 \mathrm{CE}$, como representante de los intereses del Estado central y el Senado en representación de los intereses de las CCAA, al que el art. 69 CE concibe, al menos formalmente —al margen de las distorsiones a las que conduce su elección-como la «cámara de representación territorial» ${ }^{41}$. La participación en el procedimiento del art. $155 \mathrm{CE}$ de todos los sujetos que conforman el principio autonómico es también compatible con la concepción de la decisión resultante como una función del Estado total, es decir, como una función llamada a definir el régimen jurídico al que todos los miembros del sistema descentralizado han de someterse.

\section{La relación entre coerción estatal y la jurisdicción constitucional}

Como se acaba de poner de relieve, la coerción estatal del art. 155 CE ha de ser considerada como una función del Estado total del principio autonómico. Sin embargo, llegados a este punto, el problema que se plantea es precisar cuál es su relación con la función de control, también del Estado total, que lleva a cabo ordinariamente el TC sobre el Estado central y, en lo que aquí interesa, sobre las CCAA. Como se verá, la relación existente en la CE entre la función jurisdiccional del TC y la facultad de coerción permitirá coadyuvar a definir el sentido del art. $155 \mathrm{CE}$ en la estructura del principio autonómico. No puede obviarse que, además del TC, existen otros órganos jurisdiccionales, como los que se prevén en el art. $153 \mathrm{CE}$, que ejercen también una función del Estado total controlando la actividad de las CCAA: el Tribunal de Cuentas y la jurisdicción contencioso-administrativa ${ }^{42}$.

A pesar de ello, el supuesto de hecho del art. 155 CE diseña una particular relación entre la coerción estatal y función jurisdiccional del TC. Como se ha analizado con anterioridad, el supuesto de hecho que habilita al ejercicio de la facultad del art. 155 CE no es, sin más, una conducta lesiva de la eficacia del

41 Sobre la posición garantista que desempeña el Senado respecto de las Comunidades Autónomas en el procedimiento del art. 155, véase R. Punset Blanco, El Senado y las Comunidades Autónomas, Tecnos, Madrid, 1987, pp. 204 y ss.

42 Inclusive otros órganos jurisdiccionales a los que no alude el art. 153 CE. Por ejemplo, los órganos que aplican el Código Penal, cuyas disposiciones sancionan conductas contrarias a la Constitución, como normas del Estado total. Ese es el caso, por ejemplo, de las que se recogen en el Título XXI, relativas a «los delitos contra la Constitución». 
principio autonómico. La expresa plasmación de la norma (parcial) de sujeción, junto con la de lealtad, en el art. 155 CE tiene una doble finalidad. La primera, ya ha sido analizada: exigir que el menoscabo de la eficacia del principio autonómico deba de tener su origen en una infracción cualitativa o cuantitativa de las normas de la CE o del bloque constitucional que definen el encaje de las CCAA en el sistema unitario. Y la segunda, en lo que aquí interesa, para concebir al art. $155 \mathrm{CE}$ como una facultad subsidiaria de la función jurisdiccional que lleva a cabo específicamente el TC en la estructura del principio autonómico ${ }^{43}$.

En efecto, si el art. 155 CE presupone para acreditar el incumplimiento de la norma de lealtad una infracción cuantitativa o cualitativa de la sujeción a las normas de la CE o del bloque de la constitucionalidad, tal cosa es una competencia del TC. Dicha competencia se desarrolla mediante diversos cauces procesales previstos en la LOTC: el recurso (arts. 31ss.) y la cuestión de inconstitucionalidad (arts. 35ss) y los conflictos positivos (arts. 62ss.) y negativos de competencia (arts. 68ss). Precisamente por ello, del art. $155 \mathrm{CE}$ se deduce implícitamente que el ejercicio de la facultad de coerción en el principio autonómico presupone una resolución del TC que acredite tal infracción. El art. $155 \mathrm{CE}$ regula, por tanto, una facultad subsidiaria de la garantía jurisdiccional de la norma de lealtad al principio autonómico.

Llegados a este punto, el problema que se plantea es determinar cuál es el sentido de que la CE en su art. $155 \mathrm{CE}$ haya reconocido una facultad de coerción, como función del Estado total, subsidiaria a la jurisdicción constitucional. La función del art. 155 CE en la estructura del principio autonómico puede encontrar explicación en el contenido que presenta la norma de lealtad constitucional que define su supuesto de hecho. El cumplimiento de una norma de lealtad en el sistema descentralizado quizás pudiera hacerse descansar exclusivamente en un TC cuando aquélla se limita a proscribir conductas contrarias a su eficacia. Cuando la norma de lealtad presenta dicho contenido pasivo ${ }^{44}$, el TC ejerciendo su natural función como «legislador negativo» ${ }^{45}$, puede expulsar del sistema territorialmente descentralizado las conductas de sus miembros contrarias a su eficacia. Ese efecto es el que ha producido la STC 259/2015 que, por su deslealtad con el principio autonómico, ha declarado la invalidez de la resolución del Parlamento de Cataluña 1/XI, sobre el inicio del proceso político en Cataluña.

43 Véase E. Vírgala Foruria, op. cit., pp. 81, 88. Por el contrario, otros autores niegan que la facultad del art. $155 \mathrm{CE}$ tenga un carácter subsidiario de la jurisdicción constitucional, afirmando más bien un carácter autónomo para la coerción estatal. Véase E. Albertí Rovira, op. cit., p. 472. Véase también V. CaLAfeli FERRÁ, op. cit., p. 111.

44 Véase acerca de este contenido pasivo de la norma de lealtad L. Álvarez Álvarez, op. cit., pp. 79 y ss.

45 Véase H. Kelsen, «Der Hüter der Verfassung» en H. Klekatsky, R. Marcic y H. Schambeck (edits.), Die Wiener Rechtstheoretiste Schule, Band II, Europa Verlag, Wien, 1968, p. 1873. 
Sin embargo, la norma de lealtad al principio autonómico no presenta tan solo un contenido pasivo, limitándose a prohibir las conductas contrarias a su eficacia. A pesar de que ello se deduce naturalmente también de la norma de lealtad —como han señalado las SSTC 4/1981, 64/1990— — ${ }^{46}$, aquélla asume un contenido principalmente activo, exigiendo del Estado central y de las CCAA una conducta favorable orientada a realizar su eficacia. Esto cabe deducirse, entre otros elementos, del modelo transversal de reparto competencial entre los sujetos (arts. 148-149 CE) del sistema descentralizado. Esta transversalidad evidencia que el principio autonómico solo puede ser plenamente eficaz si sus miembros las ejercen permitiendo que las atribuidas al resto, y que se proyectan en el mismo sector de la realidad, también puedan ser eficaces. Este contenido activo de la norma de lealtad constitucional, que se irradia a todo el funcionamiento del principio autonómico, ha sido reconocido en la jurisprudencia del TC (SSTC 18/1982, FJ. 14. $\left.{ }^{\circ}, 209 / 1990,166 / 2000\right)^{47}$.

Siendo esto así, para garantizar esta norma de lealtad constitucional es necesario reconocer una facultad capaz de garantizar la eficacia del principio autonómico allí donde el TC, como legislador negativo no puede llegar. Una facultad que autorice a ciertos órganos a aprobar, de manera sustitutiva, las normas y los actos jurídicamente impuestos por la norma de lealtad en orden a realizar y reforzar la eficacia del principio autonómico ${ }^{48}$. Conforme a lo hasta aquí expuesto, las «medidas necesarias» que, a través del art. $155 \mathrm{CE}$, puede adoptar el Gobierno con la autorización del Senado son normas y actos de sustitución de las conductas (positivas) que la norma de lealtad impone a las CCAA. Esto convierte al art. 155 CE en la norma de cierre del sistema autonómico, de tutela complementaria de la

46 STC 4/1981, FJ $10 .^{\circ}$ : «La autonomía no se garantiza por la Constitución — como es obvio- para incidir de forma negativa sobre los intereses generales de la Nación o sobre intereses generales distintos de los de la propia entidad». Por su parte, la STC 64/1990, FJ. 7. ${ }^{\circ}$ incide sobre ese contenido pasivo de la norma de lealtad, al reconocer que se «requiere que, en el ejercicio de sus competencias, se abstengan de adoptar decisiones o realizar actos que perjudiquen o perturben el interés general y tengan, por el contrario, en cuenta la comunidad de intereses que las vincula entre sí que no puede resultar disgregada o menoscabada a consecuencia de una gestión insolidaria de los propios intereses».

47 «...ponen de manifiesto la existencia de una situación altamente insatisfactoria en orden a la construcción y consolidación del Estado de las Autonomías configurado por nuestra Constitución, cuyo acabado diseño no se alcanzara mientras el Gobierno de la Nación no haya transferido a las Comunidades Autónomas (en este caso a Galicia) los medios personales y materiales necesarios para el ejercicio de competencias estatutariamente asumidas por aquéllas... La lealtad constitucional obliga a todos, y en el campo que nos ocupa es el Gobierno, máximo responsable de la finalización efectiva del reparto de competencias, quien debe extremar el celo por llegar a acuerdos en la Comisión Mixta con Galicia» (STC 209/1990, FJ. 4). «La atribución de una competencia sobre un ámbito físico determinado no impide necesariamente que se ejerzan otras competencias en ese espacio, siempre que ambas tengan distinto objeto jurídico, y que el ejercicio de las autonómicas no interfieran o perturben el ejercicio de las estatales, por lo que, frecuentemente, resultará imprescindible el establecimiento de mecanismos de cooperación que permitan la necesaria coordinación y cooperación entre las Administraciones Públicas implicadas» (STC 166/2000, FJ 3. ${ }^{\circ}$ ). Véase también STC 11/1986, 15/1998.

48 Cfr. entre otros J. García Torres, op. cit., pp. 1283 y ss. 
eficacia del principio autonómico allí donde la naturaleza de la función del TC como legislador negativo no puede llegar.

\section{LA FUNCIÓN SUSTITUTIVA Y EL PROCEDIMIENTO DE LA COERCIÓN ESTATAL}

\section{Las medidas sustitutivas de art. $155 \mathrm{CE}$ y las funciones constitucionales del Gobierno}

Hasta aquí se ha tenido la oportunidad de señalar que la coerción estatal ha de considerarse en la estructura del principio autonómico como una función del Estado total subsidiaria de la función jurisdiccional del TC, al servicio del cumplimiento sustitutivo de las obligaciones impuestas por el contenido activo de la norma de lealtad. Sin embargo, que la coerción estatal constituya una función del Estado total, permitiendo a los órganos previstos en el art. 155 CE «elevarse» -bajo determinadas condiciones - sobre las normas de la Constitución y del bloque constitucional que reparten competencias entre el Estado central y las CCAA y definir el régimen jurídico vinculante para éstas, no les exonera de toda sujeción a la CE. De lo contrario habría que admitirse lo que ha llegado a defender algún sector doctrinal, que ha querido ver en el art. 155 CE la plasmación de una suerte de estado de excepción, que operaría para defender el principio autonómico sin sujeción a norma alguna ${ }^{49}$.

La coerción estatal como función del Estado total únicamente permite a los órganos previstos en el art. $155 \mathrm{CE}$ no sujetarse al reparto competencial realizado por la CE y el bloque de la constitucionalidad entre el Estado central y las CCAA con la finalidad de garantizar una actividad requerida jurídicamente por el contenido activo de norma de lealtad constitucional al principio autonómico. El art. 155 CE no autoriza una falta de sujeción a los elementos orgánicos, procedimentales ni funcionales de dichos sujetos. Debe resultar de aplicación al art. 155 CE lo previsto en el art. 116,5 CE que, regulando también un derecho de excepción (STC 83/2016, FJ. 7. ${ }^{\circ}$ ), determina que el funcionamiento de los poderes

49 Véase P. Cruz Villalón, «La protección extraordinaria del Estado» en A. Pedrieri y E. García DE EnTerría (eds.), La Constitución Española de 1978, Cívitas, Madrid, 1984, p. 713. El citado autor califica al art. $155 \mathrm{CE}$ como una «dictadura constitucional», definiendo a los órganos a modo de soberanos que deciden en situaciones de excepción. Esta concepción es la que se encuentra en el trasfondo de la teoría del defensor de la Constitución que desempeñó un importante protagonismo durante la vigencia de la Constitución de Weimar de 1919 y que concibió a las facultades atribuidas al Presidente del Reich, entre ellas la ejecución estatal (art. 48,1), como una norma orientada a garantizar la preservación de ciertas decisiones políticas subyacentes al documento constitucional. Cfr. C. Sснмітт, Der Hüter der Verfassung, Duncker \& Humblot, Berlin, 1985, p. 158. También Verfassungslehre, Duncker \& Humblot, Berlin, 1985, pp. 23 y 24 . Véase también del mismo autor Die Diktatur; von den Anfängen des modernen Souveranitätsgedankens bis zum proletarischen Klassenkampf, Duncker \& Humblot, Berlin, 1978, pp. 242 y ss. 
constitucionales del Estado no podrá interrumpirse durante la vigencia de los estados de alarma, excepción y sitio.

Esta consecuencia ha sido reiterada por el TC, que ha ligado las medidas previstas en el art. $155 \mathrm{CE}$ con el ejercicio de las funciones constitucionales atribuidas al Gobierno en la CE (STC 25/1981) $)^{50}$, que actúa en el procedimiento del art. $155 \mathrm{CE}$ - como el TC predicó del también mecanismo excepcional de la declaración del estado de alarma del art. $116 \mathrm{CE}$ - en «su condición de órgano constitucional, no de órgano superior de la administración» (STC 83/2016, FJ. $10)^{51}$. Siendo esto así, hay que mantener que la facultad de sustitución de la actividad (positiva) jurídicamente impuesta a las CCAA por la norma de lealtad al principio autonómico ha de llevarse a cabo por el Gobierno mediante: 1) la función legislativa, particularmente mediante el decreto-ley (art. 86,1 CE) - cuyo presupuesto habilitante se acomoda al carácter extraordinario del art. $155 \mathrm{CE}-$, 2) la función reglamentaria, 3) la función ejecutiva y 4) la función de dirección política del Estado.

De acuerdo con lo expuesto, sería cuestionable admitir que entre las «medidas necesarias» previstas en el art. 155 CE pueda encontrarse la posibilidad de disolver los órganos autonómicos, algo que ha venido a admitir la doctrina ${ }^{52}$. Si, como se ha visto, la función del Estado total del art. $155 \mathrm{CE}$ permite solo la no sujeción al sistema de reparto competencial, imponiendo a sus órganos la observancia de las condiciones orgánicas y procedimentales establecidas en la CE y en el bloque de la constitucionalidad, ello quedaría infringido si posibilitara la suspensión de la autonomía y disolución de los órganos autonómicos. Falta en la CE una disposición similar a la contenida en el art. 100,1 de la Constitución de Austria o en el art. 126 de la Constitución de Italia que autoriza la disolución de los órganos de los sujetos descentralizados por parte del Estado central para haberlo hecho posible ${ }^{53}$.

Ciertas dificultades plantean también otras medidas que la literatura ha abarcado en la facultad del art. $155 \mathrm{CE}$, en particular, 1) la suspensión y privación de efectos jurídicos a los actos de las CCAA y 2) la suspensión de autoridades. En

50 «Aunque las Comunidades Autónomas no son ni pueden ser ajenas al interés general del Estado, la defensa específica de éste es atribuida por la Constitución al Gobierno (arts. 97, 155)...» (FJ. 3. ${ }^{\circ}$ ).

51 Véase también en ese sentido las SSTC 45/1990, FJ 2 y 196/1990, FJ 5.

52 Véase E. Vírgala Foruria, op. cit., pp. 101 y ss. Sin embargo, para el citado autor, esta medida solo es posible en el caso de que las CCAA vulneren el interés general de España. Recuérdese que el citado autor distingue en el art. 155 CE dos supuestos de hecho distintos, clasificándose las medidas a adoptar según aquéllos. Véase una posición contraria en lo que se refiere a la posibilidad de disolución de los órganos autonómicos, siguiendo un amplio parecer doctrinal, E. Albertí Rovira, op. cit., p. 474, J. García Torres, op. cit., pp. 1281 y ss., también E. GONZÁlEZ HernándEZ, «El control estatal sobre las Comunidades Autónomas: la reforma estatutaria y el supuesto de control extraordinario del artículo 155 CE. La fiscalización subsidiaria del Tribunal Constitucional», Parlamento y Constitución, n. ${ }^{\circ} 11,2008$, p. 180.

53 Véase respectivamente sobre sus condiciones y presupuestos R. Walter, H. Mayer, G. Kucsko-Stadlmayer, Bundesverfassungsrecht, 10 Aufl., Manz, Wien, 2007, p. 385, y P. Costanzo, «Art. 126» en G. Branca (ed.), Commentario della Costituzione, Zanichelli/Foro italiano, Bologna, Roma, 1990, pp. 362 y ss. 
lo que se refiere a la primera medida, si, conforme a lo expuesto, la función del art. 155 CE ha de considerarse como subsidiaria de la labor jurisdiccional del TC, la suspensión y la privación de efectos jurídicos a los actos de la CCAA ha de caer en la competencia propia del TC durante la tramitación de los procedimientos de declaración de inconstitucionalidad, antes de legitimar la aplicación del art. 155 CE. En lo que se refiere a la segunda posibilidad, la suspensión de autoridades, la nueva reforma de la LOTC ha hecho caer tal medida en el ámbito competencial del TC, cuyo art. 92,4b), como se verá, le reconoce para ejecutar sus resoluciones la posibilidad de «acordar la suspensión en sus funciones de las autoridades o empleados públicos de la Administración responsable del incumplimiento, durante el tiempo preciso para asegurar la observancia de los pronunciamientos del Tribunal».

\section{El procedimiento del art. 155 CE y vías de impugnación}

El procedimiento para el ejercicio de la coerción estatal del art. 155 CE presupone, como consecuencia de su carácter extraordinario y subsidiario, una resolución del TC que acredite la infracción reiterada o grave de la CE y del bloque de la constitucionalidad que la convierta en idónea para poner en peligro la eficacia del principio autonómico. Sin embargo, como se ha tenido la oportunidad de dejar constancia con anterioridad, no cualquier constatación por parte del TC de la infracción de la norma de lealtad por parte de las CCAA resulta suficiente por sí misma para poder activar el procedimiento del art. $155 \mathrm{CE}$. No lo es cuando lo que se contraviene es el contenido pasivo de la norma de lealtad a través de «leyes, disposiciones normativas o actos con fuerza de Ley» (art. 31, 35 LOTC) o de una «disposición o resolución» (art. 62 LOTC) contrarios a la eficacia del principio autonómico. En estos casos, la resolución del TC puede garantizar por sí misma la eficacia del principio autonómico expulsando del ordenamiento la conducta de la CA (art. 39,1, 66 LOTC). Eso es lo que sucedió con la STC 259/2015, que declaró inválida por contradicción de la norma de lealtad la Resolución del Parlamento de Cataluña 1/XI, de 9 de noviembre de 2015, «sobre el inicio del proceso político en Cataluña como consecuencia de los resultados electorales del 27 de septiembre de 2015.

Dada la función sustitutiva del art. $155 \mathrm{CE}$ en la estructura del principio autonómico, para poder activar el procedimiento del art. $155 \mathrm{CE}$ es necesaria una resolución del TC que estime vulnerado el contenido activo de la norma de lealtad. Ya sea declarando inconstitucional una omisión de las CCAA incompatible con la eficacia del principio autonómico, a través de la resolución de un conflicto negativo de competencias (art. 71 LOTC), ya sea declarando inconstitucional una norma, disposición o acto que requiera ser sustituida por otra a través del planteamiento de un recurso (art. 32 LOTC), cuestión de inconstitucionalidad (art. 35 LOTC) o conflicto positivo de competencias (art. 62 LOTC). En segundo lugar, resulta necesario que el TC, acredite el total o parcial incumplimiento de la resolución que 
impone tal deber, a través del procedimiento introducido en el art. 92,4 LOTC por su nueva reforma ${ }^{54} \mathrm{y}$, en tercer lugar, que el TC active insatisfactoriamente los mecanismos reconocidos en el art. 92,4 LOTC en orden a la ejecución de sus resoluciones: a) multa coercitiva, b) suspensión de autoridades, c) ejecución sustitutoria, d) deducción de testimonio para exigir responsabilidad penal ${ }^{55}$.

En lo que se refiere a la ejecución sustitutoria contemplada en el art. 92,4c) LOTC tal mecanismo, de carácter ordinario, no debe de ser confundido con la facultad sustitutoria de carácter extraordinario que reconoce el art. $155 \mathrm{CE}$ en la estructura del principio autonómico. La Ley de la Jurisdicción Contencioso Administrativo (LJCA) — cuyo carácter supletorio en materia de ejecución de las resoluciones del TC, se ha reconocido por la propia LOTC - determina en su art. 108,1 que, cuando una sentencia «condenara a la administración a realizar una determinada actividad o a dictar un acto», el juez o tribunal podrá, para el caso de su incumplimiento, autorizar la «ejecución subsidiaria con cargo a la administración condenada» (art. 108,1b). La doctrina administrativista ha reconocido que en ejercicio de dicha facultad el juez puede autorizar a otra administración pública una actividad sustitutiva de los actos jurídicamente debidos ${ }^{56}$, incluso «al margen del régimen ordinario de competencias», como ha reconocido el TC (STC 167/1987, FJ 2. $\left.{ }^{\circ}\right)^{57}$.

54 «En caso de advertirse que una resolución dictada en el ejercicio de su jurisdicción pudiera estar siendo incumplida, el Tribunal, de oficio o a instancia de alguna de las partes del proceso en que bubiera recaído, requerirá a las instituciones, autoridades, empleados públicos o particulares a quienes corresponda llevar a cabo su cumplimiento para que en el plazo que se les fije informen al respecto»

55 a) Imponer multa coercitiva de tres mil a treinta mil euros a las autoridades, empleados públicos o particulares que incumplieren las resoluciones del Tribunal, pudiendo reiterar la multa hasta el cumplimiento íntegro de lo mandado. b) Acordar la suspensión en sus funciones de las autoridades o empleados públicos de la Administración responsable del incumplimiento, durante el tiempo preciso para asegurar la observancia de los pronunciamientos del Tribunal. c) La ejecución sustitutoria de las resoluciones recaídas en los procesos constitucionales. En este caso, el Tribunal podrá requerir la colaboración del Gobierno de la Nación a fin de que, en los términos fijados por el Tribunal, adopte las medidas necesarias para asegurar el cumplimiento de las resoluciones. d) Deducir el oportuno testimonio de particulares para exigir la responsabilidad penal que pudiera corresponder».

56 Un detenido estudio de la sustitución interadministativa, con una fundamentación constitucional puede consultarse en M. BELTRÁN DE FELIPE, El poder de sustitución en la ejecución de las sentencias condenatorias de la administración, Civitas, Madrid, 1995, pp. 141 y ss. Véase también I. ArANGuren Pérez y J. J. GONZÁLEZ Rivas, Comentarios a la ley reguladora de la jurisdicción contenciosa administrativa 29/1990, de 13 de junio, 2. ${ }^{a}$ edición, Thomson-Civitas, Pamplona, 2008, p. 1167. Esta actuación administrativa sustitutoria ha sido, en ocasiones reconocida en la ley, como sucede con el art. 60 de la Ley de Bases de Régimen Local. En la citada disposición se afirma «Cuando una entidad local incumpliera las obligaciones impuestas directamente por la Ley de forma que tal incumplimiento afectara al ejercicio de competencias de la Administración del Estado o de la Comunidad Autónoma, y cuya cobertura económica estuviere legalmente o presupuestariamente garantizada, una u otra, según su respectivo ámbito competencial, deberá recordarle su cumplimiento concediendo al efecto el plazo que fuere necesario. Si transcurrido dicho plazo, nunca inferior a un mes, el incumplimiento persistiera, se procederá a adoptar las medidas necesarias para el cumplimiento de la obligación a costa y en sustitución de la entidad local».

57 «La titularidad de la potestad de ejecución corresponde exclusivamente a los propios órganos judiciales como una manifestación típica de la potestad jurisdiccional que la Constitución les ha conferido en su 
Sin embargo, una facultad de sustitución de la conducta jurídicamente impuesta (por la norma de lealtad) a través de normas de rango legislativo o reglamentario llamadas a desplegar su validez en los niveles superiores del ordenamiento, alterando el principio constitucional de división territorial del poder es una facultad solo posible a partir del art. $155 \mathrm{CE}^{58}$. La facultad extraordinaria de sustitución del art. 155 CE cabe ser ejercida cuando la facultad sustitutoria ordinaria reconocida en el art. 92,4 c), como las otras medidas de ejecución previstas en el art. 92,4 LOTC: a) multa coercitiva, b) suspensión de autoridades u otros empleados públicos y d) deducción de testimonio en orden a la sustanciación de la responsabilidad penal, no logra el cumplimiento de la resolución del TC.

Satisfecho el supuesto de hecho del art. 155 CE, el Gobierno incoará dicho procedimiento, debiendo de requerir previamente al Presidente de la Comunidad Autónoma para que cumpla voluntariamente con las obligaciones requeridas por el deber de lealtad. En tal requerimiento deberá hacerse constar que «en caso de no ser atendido», el Gobierno procederá a activar el cumplimiento sustitutivo en los términos previstos en el art. 155 CE. Si el Presidente de la Comunidad Autónoma no atendiera al requerimiento, el Gobierno deberá definir, en ejercicio de sus funciones constitucionales, qué actos normativos de sustitución resultan necesarios para garantizar la eficacia del principio autonómico, a fin de recabar la aprobación del Senado por mayoría absoluta.

Del art. $155 \mathrm{CE}$ cabe deducir dos límites que se infieren de lo que el TC ha denominado «derecho de excepción» (STC 83/2016, FJ. 10. ${ }^{\circ}$ ), al que ha vinculado también el art. 155 (STC 49/1988, FJ. 31. ${ }^{\circ}$ ): la temporalidad y la proporcionalidad. El Gobierno deberá de justificar, por tanto, la idoneidad, la necesidad y la proporcionalidad en sentido estricto de las medidas de sustitución para garantizar la eficacia del principio autonómico ${ }^{59}$. Una vez definidas las medidas de sustitución en el contexto de dichos límites, el Gobierno, como órgano del Estado central, habrá de solicitar la autorización de la mayoría absoluta del Senado que actúa en el procedimiento del art. $155 \mathrm{CE}$ como representante de los intereses de las CCAA.

art. 117.3. De acuerdo con ello, no compete a este Tribunal precisar cuáles sean las decisiones y medidas oportunas que en cada caso hayan de adoptarse en el ejercicio de dicha potestad jurisdiccional ejecutiva, pero sí le corresponde, en cambio, corregir y reparar las eventuales lesiones del derecho a la tutela judicial que tengan su origen en la pasividad o el desfallecimiento de los órganos judiciales para adoptar las medidas necesarias que aseguren el cumplimiento de sus propios fallos. Dentro del orden jurisdiccional contencioso-administrativo, son exigibles, en primer lugar, las que, al amparo de su legislación reguladora, deben tender a que se produzca inicialmente la actuación administrativa requerida por el pronunciamiento judicial, recabando para ello la colaboración precisa, incluso al margen del régimen ordinario de competencias».

58 Algún autor, por el contrario, ha entendido que las medidas que podrían adoptarse a través del procedimiento del art. $155 \mathrm{CE}$ son las que han sido plasmadas en el art. 92,4 de la nueva reforma de la LOTC, véase al respecto el reciente estudio de E. GonZÁlez HernándEZ, op. cit., p. 541. El problema es que ello parece convertir la coerción estatal del art. $155 \mathrm{CE}$ en un mecanismo ordinario de ejecución de las resoluciones del TC.

59 Véase E. Vírgala Foruria, op. cit., p. 99. 
A tal fin, deberá presentar por escrito ante el Presidente de la Cámara el «contenido y alcance de las medidas propuestas» y la justificación de haber realizado el requerimiento al Presidente de la Comunidad Autónoma al que se refiere el art. 155 CE y la de haber sido incumplido por éste (art. 189,1 RS). Asimismo, de lo anteriormente expuesto, cabe deducir que el Gobierno deberá acreditar también la existencia de una resolución del TC que haya declarado jurídicamente debida, por el deber de lealtad, una determinada conducta por parte de las CCAA y el empleo, sin éxito, de los mecanismos ordinarios de ejecución previstos en el art. 92,4 LOTC. Tras su remisión a la Comisión General de las CCAA o a la constituida a tal efecto (art. 189,2 RS), el Presidente del Senado requerirá al Presidente de la CA para que presente los antecedentes, datos y alegaciones y, en su caso, designe un representante ante la Comisión (art. 189,3 RS). La Comisión formulará una propuesta razonada acerca de si procede o no la aprobación de las medidas propuestas por el Gobierno, pudiendo establecer los condicionamientos y modificaciones que estime pertinentes (art. 189,4 RS).

Como se puede ver, la intervención del Senado en el procedimiento del art. 155 CE no se limita a la simple aprobación o negación de las medidas propuestas, sino que participa en representación de los intereses de las CCAA codefiniendo con el Gobierno-como órgano del Estado central-las medidas necesarias que constituyen el ejercicio de una función del Estado total del principio autonómico. El Pleno del Senado habrá de proceder a la votación por mayoría absoluta la propuesta presentada (art. 189,5 RS). Una vez aprobadas dichas medidas, el Gobierno procederá a publicar en el Boletín Oficial de la CA y en el del Estado, las normas y actos llamados a sustituir la actividad de las CCAA en cumplimiento con su deber de lealtad con el principio autonómico. También, como reconoce el art. 155,2 CE, las posibles instrucciones vinculantes que, para la ejecución de las citadas medidas, se dirigen a las autoridades de las CCAA.

La reciente jurisprudencia del TC ha permitido delimitar los mecanismos procesales que cabría activar frente a las medidas que han sido objeto de aprobación a través del descrito procedimiento del art. $155 \mathrm{CE}$. Con anterioridad se ha puesto de manifiesto, con aval de la jurisprudencia del TC, que las medidas del art. $155 \mathrm{CE}$ han de definirse a partir de las funciones constitucionales que han sido atribuidas al Gobierno por el art. $97 \mathrm{CE}$, que abarca el ejercicio de la función legislativa, de la reglamentaria y de la ejecutiva, además de la de dirección política del Estado. El TC tuvo la ocasión de determinar con relación al decreto que declara el estado de alarma que, si bien, asume formalmente un rango reglamentario, ha de considerarse como una norma «con rango o valor de ley», al igual que el acto del Congreso de los Diputados que declara su prórroga o modificación.

Para el TC, las alocuciones «valor de ley», «rango de ley» o «fuerza de ley» no quedan limitadas en nuestro ordenamiento a actos o decisiones de origen parlamentario pudiendo también predicarse de las decisiones del Gobierno (ATC 7/2012; FJ. 3. ${ }^{\circ}$ ). Ese carácter se lo otorga su consideración como derecho 
de excepción, «en la medida en que viene a excepcionar, modificar o condicionar durante ese periodo la aplicabilidad de determinadas normas, entre las que pueden resultar afectadas leyes, normas o disposiciones con rango de ley, cuya aplicación puede suspender o desplazar» (STC 83/2016, FJ. 10..$\left.^{\circ}\right)^{60}$. Esa función la desempeña, como se ha puesto de manifiesto, la facultad excepcional regulada en el art. 155 CE que plasma una función del Estado total en la estructura del principio autonómico. Por lo tanto, tanto las normas y actos del Gobierno, como la autorización del Senado, adoptadas en el marco del procedimiento del art. $155 \mathrm{CE}$, han de considerarse «disposiciones o actos con fuerza de ley», impugnables a través de la vía del recurso de inconstitucionalidad, como dispone el art. 32 LOTC.

Es a través de dicho mecanismo procesal por el que caben fiscalizarse los límites a la facultad del art. 155 CE: el respeto a las condiciones orgánico-procedimentales para la aprobación de las medidas, su temporalidad y su proporcionalidad. No cabría, por la concepción del art. 155 CE como la plasmación de una función del Estado total del principio autonómico, enjuiciar una posible intromisión de aquellas medidas en el ámbito competencial de las CCAA, ya que el sentido del art. $155 \mathrm{CE}$ es justamente autorizar, previa declaración por parte del TC, la no sujeción a las normas constitucionales y del bloque de la constitucionalidad, una facultad de sustitución de las normas y actos jurídicamente debidos por el contenido activo de la norma de lealtad al principio autonómico. En cualquier caso, al margen del recurso de inconstitucionalidad, cabe interponer un recurso de amparo contra los actos de aplicación de las citadas disposiciones.

60 «La decisión gubernamental viene así a integrar en cada caso, sumándose a la Constitución y a la Ley Orgánica 4/1981, el sistema de fuentes del derecho de excepción, al complementar el derecho de excepción de aplicación en el concreto estado declarado. Y esta legalidad excepcional que contiene la declaración gubernamental desplaza durante el estado de alarma la legalidad ordinaria en vigor, en la medida en que viene a excepcionar, modificar o condicionar durante ese periodo la aplicabilidad de determinadas normas, entre las que pueden resultar afectadas leyes, normas o disposiciones con rango de ley, cuya aplicación puede suspender o desplazar. Esta incidencia sobre la legislación vigente antes de la declaración del estado de alarma, incluidas las normas con rango de ley que pudieran verse afectadas, encuentra cobertura en el propio texto constitucional (art. 116.2 CE) y en la Ley Orgánica 4/1981 (art. 6), que imponen como contenido necesario del decreto en el que se formaliza la decisión gubernamental de la declaración la determinación de «los efectos del estado de alarma», efectos que pueden implicar, como se dijo en el ATC 7/2012, «excepciones o modificaciones pro tempore en la aplicabilidad de determinadas normas del ordenamiento vigente, incluidas, en lo que ahora importa, determinadas disposiciones legales, que sin ser derogadas o modificadas sí pueden ver alterada su aplicabilidad ordinaria» (FJ 4). Esto es, la propia Constitución y la ley reclamada por el art. 116.1 CE para desarrollar sus previsiones habilitan los efectos jurídicos que sobre la legislación en vigor antes de la declaración, incluidas las normas con rango de ley, tiene o puede tener la decisión gubernamental que, revistiendo la forma de decreto del Consejo de Ministros, proclama el estado de alarma. Así pues, aunque formalizada mediante decreto del Consejo de Ministros, la decisión de declarar el estado de alarma, dado su contenido normativo y efectos jurídicos, debe entenderse que queda configurada en nuestro ordenamiento como una decisión o disposición con rango o valor de ley. Y, en consecuencia, queda revestida de un valor normativo equiparable, por su contenido y efectos, al de las leyes y normas asimilables cuya aplicación puede excepcionar, suspender o modificar durante el estado de alarma». 


\section{CONCLUSIONES}

El constituyente español de 1978 pretendió incorporar al funcionamiento del Estado autonómico la categoría de la coerción federal (Bundeszwang) plasmada en el art. 37 de la Ley Fundamental de Bonn. De manera similar a lo previsto en esta disposición, el art. $155 \mathrm{CE}$ ha reconocido a ciertos órganos del Estado central (el Gobierno y el Senado) un poder de coerción para garantizar el cumplimiento de las obligaciones que el principio autonómico impone a las CCAA. Sin embargo, la estructura que ha asumido este principio en la CE de 1978, bien distinta al federal, distancia la función de la coerción estatal del art. 155 CE de la coerción federal del art. 37 de la Ley Fundamental.

El principio de unidad del Estado federal surge como consecuencia de la libre voluntad de los sujetos descentralizados, cuya existencia es previa a aquél. Justamente por ello, el principio federal puede presuponer en su funcionamiento la lealtad de aquellos sujetos a la unidad y responder por medio de una coerción federal construida a partir de la idea de sujeción. Eso es lo que sucede en el art. 37 de la Ley Fundamental, que autoriza a ciertos órganos del Estado central a ejercer la coerción frente a los Länder en el caso de que «simplemente» infrinjan las obligaciones jurídicamente impuestas por la Constitución y por las leyes federales.

Por el contrario, el Estado autonómico se descentraliza a partir de una unidad jurídica previa (art. 2 CE). Por ello, el principio autonómico — de manera contraria a lo que sucede con el federal- no puede presuponer en su funcionamiento la lealtad de las CCAA a dicha unidad. Eso es lo que justifica que el principio autonómico, al tiempo que reconoce a ciertos órganos del Estado central la posibilidad de efectuar la descentralización territorial aprobando las leyes del bloque de la constitucionalidad, retenga un control sobre la lealtad de las CCAA al funcionamiento del Estado autonómico. El supuesto de hecho de la coerción estatal del art. $155 \mathrm{CE}$ - de forma contraria a lo que sucede con la coerción federal-es justamente el incumplimiento por parte de las CCAA de las obligaciones impuestas por el deber de lealtad.

La coerción estatal del art. $155 \mathrm{CE}$ responde, en concreto, frente a las conductas de las CCAA que infrinjan de manera cualitativa o cuantitativa las normas de la CE y del bloque de la constitucionalidad que regulan sus órganos, sus procedimientos y sus competencias, poniendo en peligro el eficaz funcionamiento del principio autonómico. Ese es el contenido constitucionalmente más adecuado del supuesto de hecho previsto en el enunciado del art. $155 \mathrm{CE}$ : «si una Comunidad Autónoma no cumpliere las obligaciones que la Constitución u otras leyes le impongan, o actuare de forma que atente gravemente al interés general de España».

La necesidad de que el menoscabo de la eficacia del principio autonómico tenga que tener su origen en una infracción cuantitativa o cualitativa de las normas de la CE y del bloque de la constitucional, hace recaer la constatación del supuesto de hecho del art. $155 \mathrm{CE}$ en la competencia del TC. Algo que lleva a cabo a través de los mecanismos procesales del recurso, de la cuestión de incons- 
titucionalidad, del conflicto positivo y negativo de competencias. La facultad del art. $155 \mathrm{CE}$ ha de considerarse, en consecuencia, como subsidiaria de la función del TC. Llegados a este punto, surge la necesidad de tener que explicar el sentido que puede tener el reconocimiento en el art. $155 \mathrm{CE}$ de un poder subsidiario al TC destinado a garantizar el cumplimiento de la norma de lealtad por parte de las CCAA. Esto encuentra justificación en el particular contenido que asume la norma de lealtad al principio autonómico.

El cumplimiento de una norma de lealtad en el sistema descentralizado quizás pudiera hacerse descansar exclusivamente en un TC si aquélla se limitara a proscribir las conductas contrarias a su eficacia. Cuando la norma de lealtad presenta este contenido pasivo, el TC, ejerciendo su natural función de legislador negativo, puede expulsar del sistema territorialmente descentralizado las conductas de sus miembros contrarias a su eficacia. Sin embargo, como ha reconocido el TC, la norma de lealtad al principio autonómico asume un contenido activo. Esto es, no solo proscribe los comportamientos contrarios a su eficacia, sino que exige principalmente de sus miembros una conducta favorable a realizar y reforzar su eficacia.

Para garantizar este contenido activo de la norma de lealtad constitucional resulta necesario reconocer en el seno del sistema descentralizado una facultad capaz de garantizar la eficacia del principio autonómico allí donde el TC, como legislador negativo, no puede llegar. Una facultad que autorice a ciertos órganos a aprobar, de manera sustitutiva, las normas y los actos jurídicamente impuestos por la norma de lealtad en orden a realizar y reforzar la eficacia del principio autonómico. Esa es la función que desempeña el art. $155 \mathrm{CE}$ en el principio autonómico. Las «medidas necesarias» a las que alude art. $155 \mathrm{CE}$, que solo pueden ser puestas en práctica en el caso de que fracasen los medios de ejecución de las resoluciones del TC previstos en el art. 92,4 LOTC, han de adoptarse en el marco de las funciones constitucionales atribuidas al Gobierno: función legislativa, reglamentaria, ejecutiva y de dirección política del Estado. Tales medidas han de ser aprobadas por la mayoría absoluta del Senado.

Estas medidas de sustitución solo habilitan a dichos órganos a no sujetarse a las normas de la CE y del bloque constitucional que reparten competencias entre el Estado y las CCAA, no a las que regulan órganos y procedimientos. Algo que ha avalado el TC al definir lo que ha denominado «el derecho de excepción» en la CE. Por ello las «medidas necesarias» a las que alude el art. $155 \mathrm{CE}$, definidas a partir de las funciones constitucionales del Gobierno, solo pueden ejercer de manera proporcionada y temporalmente limitada competencias atribuidas inicialmente a las CCAA, pero no disolver sus órganos ni alterar los procedimientos de su elección.

$* * *$

TITLE: State coercion of art. 155 SC in the structure of the autonomous State

ABSTRACT: The Spanish constituent recognized in the art. 155 of the Constitution a category of the tradition of the German decentralized system: the state coercion. The state coercion emerges during the period 
of the confederation of the nineteenth century to supply the deficiences of the constitutional justice, attributing to the central state organs different faculties to ensure the fulfillment the constitutional (and legal) obligations by the members of the decentralized system. The engagement of state coercion presents problems in a decentralized system built from a Constitution as supreme law, whose protection is attributed to a Constitutional Court. This work has attempted to analyze the role of state coercion of art. 155 SC in the structure of the autonomous State.

RESUMEN: El constituyente español ha plasmado en el art. 155 CE una categoría de larga trayectoria en el sistema descentralizado alemán: la coerción estatal. La coerción estatal surge en el periodo de la confederación del siglo XIX para suplir las carencias de la justicia constitucional, atribuyendo a órganos del Estado central la facultad de garantizar el cumplimiento de las obligaciones impuestas por la Constitución (y las leyes) al resto de miembros del sistema descentralizado. El encaje de la coerción estatal presenta problemas en un sistema descentralizado construido a partir de una Constitución como norma suprema, cuya tutela le corresponde a un Tribunal Constitucional. Este trabajo ha pretendido analizar la función que puede desempeñar la coerción estatal del art. 155 CE en la estructura del Estado autonómico.

KEY WORDS: State coercion, Decentralized system, 155 CE.

Palabras Clave: Coerción estatal, Sistema descentralizado, 155 SC.

FECHA DE RECEPCIÓN: 05.06.2016

FECHA DE ACEPTACIÓN: 27.07.2016 